\title{
A simple model for predicting soil temperature in snow-covered and seasonally frozen soil: model description and testing
}

\author{
K. Rankinen ${ }^{1}$, T. Karvonen ${ }^{2}$ and D. Butterfield ${ }^{3}$ \\ ${ }^{1}$ Finnish Environment Institute, P.O.Box 140, FIN-00251 Helsinki, Finland \\ ${ }^{2}$ Water Resources Engineering, Helsinki University of Technology, P.O.Box 5200, FIN-02015 HUT, Finland \\ ${ }^{3}$ Aquatic Environments Research Centre, Department of Geography, University of Reading, Reading, RG6 6AB, UK \\ E-mail for corresponding author: Katri.Rankinen@ymparisto.fi
}

\begin{abstract}
Microbial processes in soil are moisture, nutrient and temperature dependent and, consequently, accurate calculation of soil temperature is important for modelling nitrogen processes. Microbial activity in soil occurs even at sub-zero temperatures so that, in northern latitudes, a method to calculate soil temperature under snow cover and in frozen soils is required. This paper describes a new and simple model to calculate daily values for soil temperature at various depths in both frozen and unfrozen soils. The model requires four parameters: average soil thermal conductivity, specific heat capacity of soil, specific heat capacity due to freezing and thawing and an empirical snow parameter. Precipitation, air temperature and snow depth (measured or calculated) are needed as input variables. The proposed model was applied to five sites in different parts of Finland representing different climates and soil types. Observed soil temperatures at depths of 20 and $50 \mathrm{~cm}$ (September 1981-August 1990) were used for model calibration. The calibrated model was then tested using observed soil temperatures from September 1990 to August 2001. R ${ }^{2}$-values of the calibration period varied between 0.87 and 0.96 at a depth of $20 \mathrm{~cm}$ and between 0.78 and 0.97 at $50 \mathrm{~cm}$. $\mathrm{R}^{2}$-values of the testing period were between 0.87 and 0.94 at a depth of $20 \mathrm{~cm}$, and between 0.80 and 0.98 at $50 \mathrm{~cm}$. Thus, despite the simplifications made, the model was able to simulate soil temperature at these study sites. This simple model simulates soil temperature well in the uppermost soil layers where most of the nitrogen processes occur. The small number of parameters required means that the model is suitable for addition to catchment scale models.
\end{abstract}

Keywords: soil temperature, snow model

\section{Introduction}

Human activities have altered the global nitrogen cycle significantly (Vitousek et al., 1997). The rate of nitrogen input into the terrestrial nitrogen cycle has approximately doubled during recent decades and the transfer of nitrogen via rivers to estuaries has greatly increased. In many terrestrial, freshwater and marine ecosystems, nitrogen plays an important role in controlling species composition, diversity and functioning. Increasing demands to decrease eutrophication of surface waters have emphasised needs for monitoring and controlling nutrient loading from point and diffuse sources. The estimation of diffuse loading is highly dependent on hydrology and meteorology, and year-to-year variation is considerable. Modelling of nitrogen processes is needed for achieving a better understanding of where water protection actions should be taken. Accurate modelling of nitrogen processes requires inclusion of environmental variables which limit process rates.

Microbial processes in soil are moisture-, nutrient- and temperature-dependent. Traditionally, microbial processes have been assumed to cease at low temperatures. For example, $\mathrm{N}$ mineralisation is assumed to occur in the temperature range $5-35^{\circ} \mathrm{C}$ (Stanford et al., 1973). However, microbial activity in soil has been observed even at subzero temperatures (Clein and Schimel, 1995; Kähkönen et al., 2001). Schmidt et al. (1999) did not find any evidence for an extensive microbial winter die-back, and both immobilisation and net mineralisation of $\mathrm{N}$ and $\mathrm{P}$ occurred in soil. Nowadays it is generally assumed that some $\mathrm{N}$ mineralisation in soils occurs in winter in northern latitudes 
(Stottlemyer and Toczydlowski, 1999). Snow is an effective insulator of heat and, thus, the soil temperature is typically only a few degrees below zero in snow-covered soil, which enables $\mathrm{N}$ transformation processes to continue throughout the winter.

Soil microorganisms are more active in upper layers than in deeper soil layers. For example, Persson and Wirén (1995) found that, on average, $78 \%$ of the net $\mathrm{N}$ mineralisation occurred above a depth of $10 \mathrm{~cm}$ and $22 \%$ occurred in the $10-50 \mathrm{~cm}$ layer in forest soils. To model $\mathrm{N}$ mineralisation and other microbial processes in soil, an accurate method for calculating soil surface layer temperatures in winter is needed. To restrict microbial processes by temperature, the simulation of soil temperature is most important in surface layers.

Soil temperature in seasonally frozen soil can be calculated from the coupled differential equations describing water and heat flow (Karvonen, 1988). These equations can be solved by numerical methods as given by for example, Harlan (1973), Taylor and Luthin (1978), Guymon et al. (1980) and Jansson and Karlberg (2001). The basic assumptions behind the two equations are very simple: the law of conservation of mass and energy, and water and heat flow as a result of gradients in water potential (Darcy's Law) and temperature (Fourier's law). The calculations of water and heat flows are based on soil properties: the water retention curve, unsaturated and saturated hydraulic conductivity, heat capacity including the latent heat at thawing/melting and the thermal conductivity. However, the combined solution of water and heat flow is impractical at the catchment-scale due to the wide spatial and temporal heterogeneity in the soil properties.

The aim of this work was to describe a new and simple model, applicable at the catchment-scale, that can be used to calculate daily values for soil temperature at various depths in both unfrozen and frozen soil and which includes the influence of snow cover. This model is based on simplification of the partial differential equations for combined water and heat flow. The input data required by the model are observed daily average air temperature and observed or modelled daily snow depth. In total, the model requires four parameters, three of which have a clear physical interpretation. The proposed soil temperature model was applied to five sites in different parts of Finland representing different climates and soil types. Observed soil temperatures (September 1981-August 1990) were used for model calibration. The calibrated model was then tested using observed soil temperatures from September 1990 to August 2001 .

\section{Material and methods}

\author{
MODEL DESCRIPTION
}

The combined heat and water flow in seasonally frozen soils is given by Eqns.(1) and (2) (e.g. Karvonen, 1988):

$$
\begin{gathered}
C_{S} \frac{\partial T}{\partial t}-\rho_{I} L_{F} \frac{\partial I}{\partial t}=\frac{\partial}{\partial z}\left[K_{T}(\theta) \frac{\partial T}{\partial z}\right]-C_{W} q_{W} \frac{\partial T}{\partial z} \\
C(h) \frac{\partial h}{\partial t}+\frac{\rho_{I}}{\rho_{W}} \frac{\partial I}{\partial t}=\frac{\partial}{\partial z}\left[K(h)\left(\frac{\partial h}{\partial z}+1\right)\right]-S(h)
\end{gathered}
$$

where $z$ is a space coordinate $(\mathrm{m}), t$ is time (days), $T$ is temperature $\left({ }^{\circ} \mathrm{C}\right), K_{T}$ is soil thermal conductivity $\left(\mathrm{W} \mathrm{m}^{-3}{ }^{\circ} \mathrm{C}^{-1}\right), L_{F}$ is latent heat of fusion of water $\left(3.34 \times 10^{5}\right.$ $\left.\mathrm{J} \mathrm{kg}^{-1}\right), C_{S}$ is volumetric specific heat of soil $\left(\mathrm{J} \mathrm{m}^{-3}{ }^{\circ} \mathrm{C}^{-1}\right), r_{I}$ and $r_{W}$ are density of ice and water $\left(\mathrm{kg} \mathrm{m}^{-3}\right)$ respectively (917 and $\left.1000 \mathrm{~kg} \mathrm{~m}^{-3}\right), C_{W}$ is specific heat of water $(4.18$ $\left.\times 10^{6} \mathrm{~J} \mathrm{~m}^{-3}{ }^{\circ} \mathrm{C}^{-1}\right), q_{W}$ is flow of water $\left(\mathrm{m} \mathrm{s}^{-1}\right), q$ is volumetric water content $\left(\mathrm{m}^{3} \mathrm{~m}^{-3}\right), I$ is volumetric ice content $\left(\mathrm{m}^{3} \mathrm{~m}^{-3}\right)$, $h$ is soil water potential $(\mathrm{m}), C(h)$ is differential moisture capacity $\left(\mathrm{m}^{-1}\right), K(h)$ is unsaturated hydraulic conductivity of the soil matrix $\left(\mathrm{m} \mathrm{s}^{-1}\right)$ and $S(h)$ is the sink term $\left(\mathrm{m}^{3} \mathrm{~m}^{-3}\right)$ representing the volume of water taken up by the roots. The numerical solution of (1) and (2) is difficult due to the terms including the volumetric ice content $I$, since they generally dominate the solution in frozen soil (e.g. Guymon et al., 1980).

Simplification of Eqns. (1) and (2) is achieved primarily by ignoring the influence of changes in soil water content on soil temperature. This assumption is clearly not valid under extremely dry or wet conditions, but it simplifies Eqns.(1) and (2) considerably. By assuming constant water content over time, it is not necessary to solve Eqn.(2) and all water-related variables with the exception of the ice term can be left out from Eqn. (1). The equation to be solved is therefore:

$$
C_{S} \frac{\partial T}{\partial t}-\rho_{I} L_{F} \frac{\partial I}{\partial t}=\frac{\partial}{\partial z}\left[K_{T} \frac{\partial T}{\partial z}\right]
$$

In the solution of Eqn. (3), the time derivatives of ice content $I$ with respect to time must be eliminated. The total water content $\theta_{T O T}\left(\mathrm{~m}^{3} \mathrm{~m}^{-3}\right)$ is the sum of unfrozen water content $\theta$ and ice content $I$ :

$$
\theta_{T O T}=\theta+I
$$

Take partial derivatives of (4) with respect to time:

$$
\frac{\partial \theta_{T O T}}{\partial t}=\frac{\partial \theta}{\partial t}+\frac{\partial I}{\partial t}
$$


In the solution, it is assumed that total water content $\theta_{T O T}$ does not change over time, which leads to:

$$
\frac{\partial I}{\partial t}=-\frac{\partial \theta}{\partial t}=-\frac{\partial \theta}{\partial T} \frac{\partial T}{\partial t}
$$

It is now possible to substitute Eqn. (6) into Eqn. (3) to get:

$$
\left(C_{S}+\rho_{I} L_{F} \frac{\partial \theta}{\partial T}\right) \frac{\partial T}{\partial t}=\frac{\partial}{\partial z}\left[K_{T} \frac{\partial T}{\partial z}\right]
$$

which is solved in the proposed model, and which can be re-written to yield:

$$
C_{A} \frac{\partial T}{\partial t}=\frac{\partial}{\partial z}\left[K_{T} \frac{\partial T}{\partial z}\right]
$$

where the apparent heat capacity $C_{A}$ is defined as

$$
C_{A}=\left(C_{S}+\rho_{I} L_{F} \frac{\partial \theta}{\partial T}\right)
$$

Not all water in the soil will freeze when the temperature is below zero, but the lower the temperature, the less water is left unfrozen. Since it is very difficult to identify the form of this function it is assumed here that the apparent heat capacity term $C_{A}$ needed in Eqn. (8) can be simplified from Eqn. (9) in such a way that the latent part is replaced by one single parameter $C_{I C E}$, which takes into account the energy released when water is frozen and the energy consumed when frozen soil melts:

$$
C_{A}=\left(C_{S}+\rho_{I} L_{F} \frac{\partial \theta}{\partial T}\right) \approx C_{S}+C_{I C E}
$$

Now consider the heat balance of a soil layer with thickness $2 Z_{s}$, with the point of interest lying in the middle of the layer at depth $Z_{S}(\mathrm{~m})$. Simple explicit finite difference approximation can be developed for this layer from Eqn. (8) as given below:

$$
C_{A} \frac{T_{Z}^{t+1}-T_{Z}^{t}}{\Delta t}=K_{T}\left[\frac{T_{S U R F}-2 T_{Z}^{t}+T_{S, L O W}}{\left(2 Z_{S}\right)^{2}}\right]
$$

where $T_{Z}^{t+1}$ is the unknown soil temperature at depth $Z_{S}$ at time $t+1, T_{Z}{ }^{t}$ is the calculated soil temperature from the previous day, $K_{T}$ is soil thermal conductivity, $T_{\text {SURF }}\left({ }^{\circ} \mathrm{C}\right)$ is the soil surface temperature and $T_{S, L O W}\left({ }^{\circ} \mathrm{C}\right)$ is soil temperature at depth $2 Z_{S}$. In the calculations it is assumed that $T_{S U R F}$ can be replaced by measured air temperature $T_{A I R}{ }^{t}$ $\left({ }^{\circ} \mathrm{C}\right)$. To avoid the computation of the whole soil temperature profile it is assumed that $T_{S, L O W}$ is equal to $T_{Z}{ }^{t}$. This assumption creates a bias in the calculated soil temperatures, since it implicitly implies that there is no heat flow below the layer under consideration, but it greatly simplifies the model allowing practical application. By substituting $T_{A I R}{ }^{t}$ in Eqn. (11) it is possible to derive the equation to be used for calculating temperature $T_{*}^{t+1}$, which does not yet include the correction due to snow cover:

$$
T_{*}^{t+1}=T_{Z}^{t}+\frac{\Delta t K_{T}}{C_{A}\left(2 Z_{S}\right)^{2}}\left[T_{A I R}^{t}-T_{Z}^{t}\right]
$$

The influence of snow cover is taken into account by an empirical equation (Rankinen et al., 2004):

$$
T_{Z}^{t+1}=T_{*}^{t+1} e^{-f_{S} D_{S}}
$$

where $f_{S}$ is an empirical damping parameter $\left(\mathrm{m}^{-1}\right)$ and $D_{S}$ is snow depth (m). Equation (13) implies that the effect of the density of snow on heat flow is ignored, although the thermal conductivity of snow depends heavily on its density.

In summary, the proposed new model operates as follows:

1. Give the initial value for soil temperature at depth $Z_{S}$ at time $t=0$.

2. Calculate temperature $T_{*}{ }^{t+1}$ from Eqn. (12) using the measured value for air temperature $T_{A I R}{ }^{t}$ and a known value for soil temperature from the previous day (either an initial value or a calculated value), $T_{Z}{ }^{t}$.

3. Calculate the new soil temperature at depth $Z_{S}$ for time $t+1$, i.e. $T_{Z}^{t+1}$ from Eqn. (13).

The four parameters required by the model are average soil thermal conductivity $K_{T}\left(\mathrm{Wm}^{-1}{ }^{\circ} \mathrm{C}^{-1}\right)$, specific heat capacity of soil $C_{S}\left(\mathrm{~J} \mathrm{~m}^{-3}{ }^{\circ} \mathrm{C}^{-1}\right)$, specific heat capacity due to freezing and thawing (latent part) $C_{I C E}\left(\mathrm{~J} \mathrm{~m}^{-3}{ }^{\circ} \mathrm{C}^{-1}\right)$ and an empirical snow parameter $f_{S}\left(\mathrm{~m}^{-1}\right)$. Typical values for $K_{T}$ are around $0.4-0.8 \mathrm{Wm}^{-1}{ }^{\circ} \mathrm{C}^{-1}$ and for $C_{S}$ around $1.0 \times 10^{6}-$ $1.3 \times 10^{6} \mathrm{~J} \mathrm{~m}^{-3}{ }^{\circ} \mathrm{C}^{-1}$, respectively (e.g. Karvonen, 1988; Tamm, 2002). This implies that thermal diffusivity usually varies in the range $3 \times 10^{-7}$ to $8 \times 10^{-7} \mathrm{~m}^{2} \mathrm{~s}^{-1}$. An approximation for $C_{I C E}$ can be obtained by assuming that the amount of frozen water content is around $0.1-0.3 \mathrm{~m}^{3} \mathrm{~m}^{-3}(\approx \Delta \theta)$ when soil temperature falls from $0{ }^{\circ} \mathrm{C}$ to -3 or to $-5{ }^{\circ} \mathrm{C}(\approx \Delta T)$ and substitution of these values to Eqn. (10) gives a probable range to parameter $C_{I C E}$, which is $4 \times 10^{6}$ to $15 \times 10^{6} \mathrm{~J} \mathrm{~m}^{-3}$ ${ }^{\circ} \mathrm{C}^{-1}$.

The input data required by the model are observed daily average air temperature and observed or modelled daily snow depth. In total, the model requires four parameters, three of which have a clear physical interpretation. In this application, modelled snow depths were used instead of observed ones, because the daily snow depth measurements needed in Eqn. (13) are generally not available at catchment scale. The snow model used in the test examples is based on a simple degree-day model developed by Vehviläinen 
(1992). Karvonen (2003) added a simple routine to the original model for calculation of snow density and snow depth.

\section{STUDY SITES AND DATA}

Measurements of precipitation, air temperature, soil temperature and snow depth from the observation stations of the Finnish Meteorological Institute were used in this study. The observation stations (Jokioinen Observatory 1201, Kuopio Airport 3603, Oulu Airport 5401, Sodankylä Observatory 7501) were chosen to represent different

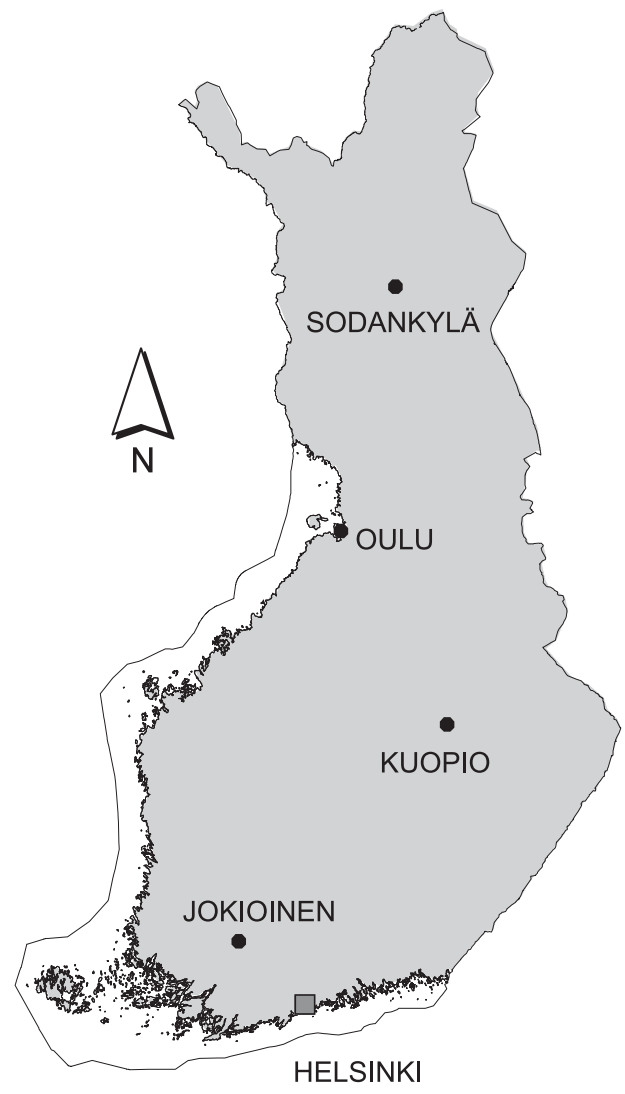

Fig. 1. Location of the study sites vegetation zones in Finland (Hämet-Ahti, 1981). Mean air temperatures and average precipitation at these observation stations in 1971-2000 are presented in Table 1, which includes the coordinates and local soil types. The locations of the observation stations are shown in Fig. 1.

Both snow depth and soil temperature measurements (at depths of $20 \mathrm{~cm}$ and $50 \mathrm{~cm}$ ) at these observation stations, or other stations close by, were available. At Sodankylä, both snow depth and soil temperature measurements were available at two locations (Sodankylä Observatory 7501 and Sodankylä Vuotso 8602). Snow depths were measured daily and soil temperature usually four times a month. Daily snow depth measurements were not available for the whole period and therefore measured snow depths were used only to calibrate the snow model and the calculated snow depths were used in Eqn. (13) when taking into account the effect of snow depth on soil temperature.

Data from 1981-1990 were used to calibrate the soil temperature model and data from 1991-2002 were used to test it. Observational practices and methods at the Jokioinen Observatory (1201) have changed considerably since the 1990s (Drebs et al., 2002) and observations earlier made manually by staff on site are now taken by automatic equipment. However, no effect of transition from manual to automated methods on the consistency of the data can be seen (Fig. 2).

\section{TESTING OF THE PROPOSED MODEL}

The goodness of fit of the soil temperature simulations was determined by calculating $\mathrm{R}^{2}$-values. The coefficient of determination, $\mathrm{R}^{2}$, was calculated as given by Nash and Sutcliffe (1970):

$$
\begin{array}{r}
R^{2}=1-\frac{S_{E}}{S_{M}} ; S_{M}=\sum_{i=1}^{N}\left(D_{m, i}-D_{a v}\right)^{2} ; \\
S_{E}=\sum_{i=1}^{N}\left(D_{m, i}-D_{c, i}\right)^{2}
\end{array}
$$

Table 1. Mean air temperature and average precipitation in 1971-2000 according to Drebs et al. (2002) and vegetation zone

\begin{tabular}{|c|c|c|c|c|c|}
\hline Station & Coordinates & $\begin{array}{l}P \\
(\mathrm{~mm})\end{array}$ & $\begin{array}{l}T \\
\left({ }^{\circ} \mathrm{C}\right)\end{array}$ & Soil type & Vegetation zone \\
\hline 1201 Jokioinen, Observatory & $\left(60^{\circ} 49,23^{\circ} 30\right)$ & 607 & 4.3 & clay & Southern boreal \\
\hline 3601 Kuopio, Airport & $\left(63^{\circ} 01,27^{\circ} 48\right)$ & 608 & 3.1 & loamy sand & Southern boreal \\
\hline 5401 Oulu, Airport & $\left(64^{\circ} 56,25^{\circ} 22\right)$ & 446 & 2.4 & sandy loam & Middle boreal \\
\hline 7501 Sodankylä, Observatory & $\left(67^{\circ} 22,26^{\circ} 37\right)$ & 507 & -0.8 & till & Northern boreal \\
\hline 8602 Sodankylä, Vuotso & $\left(68^{\circ} 05,27^{\circ} 11\right)$ & 507 & -0.8 & sand & Northern boreal \\
\hline
\end{tabular}
according to Hämet-Ahti (1981) 

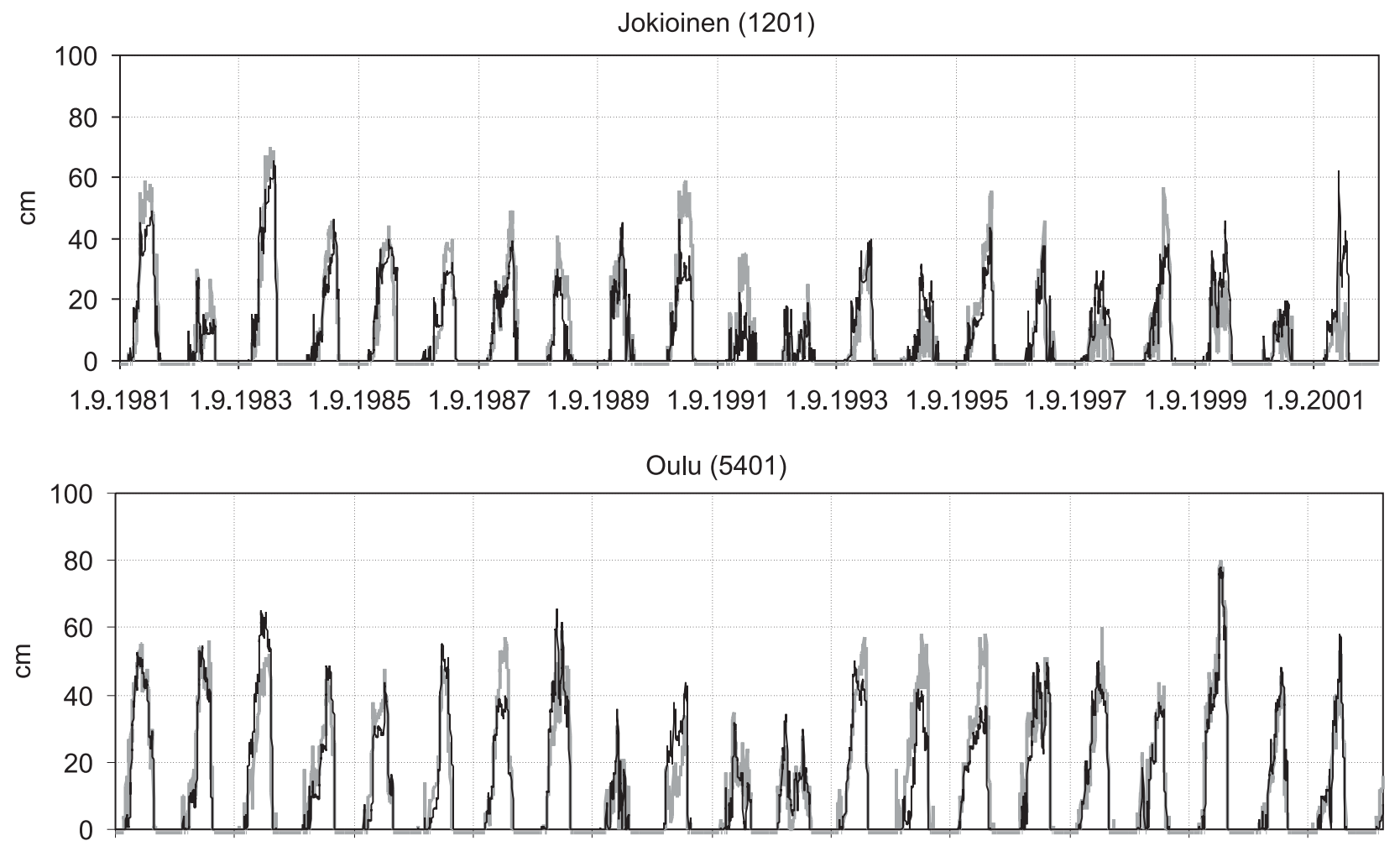

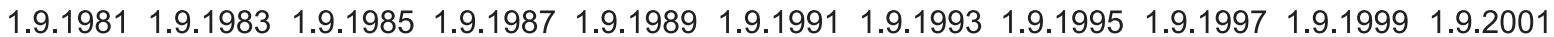

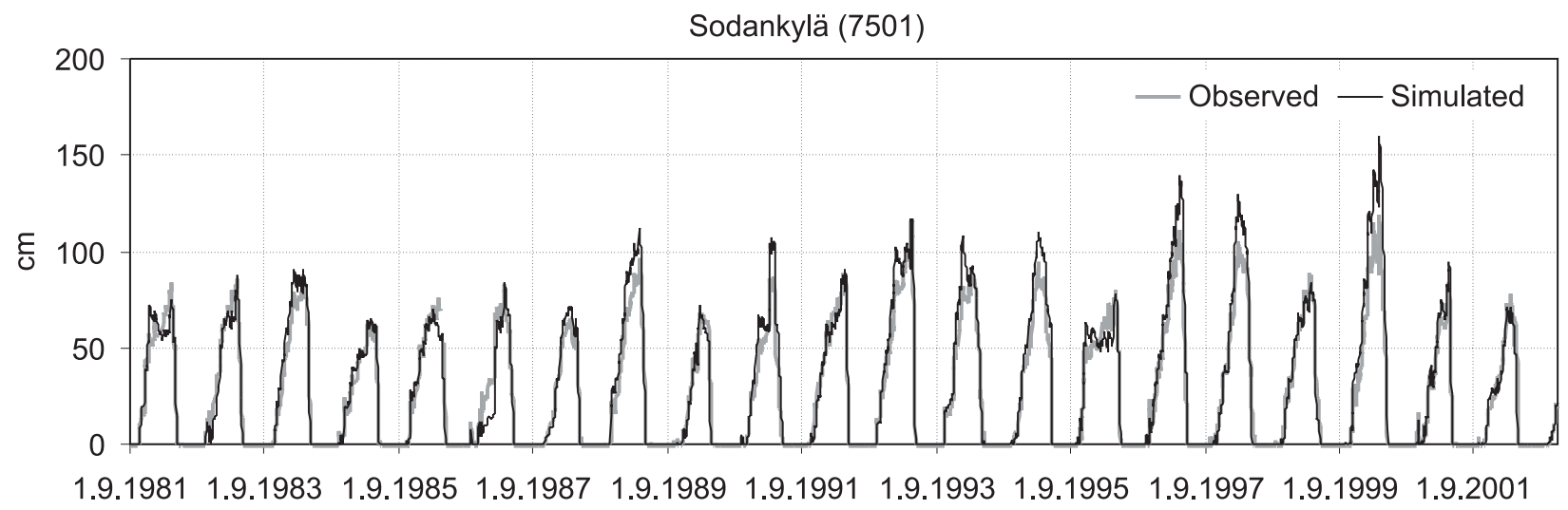

Fig. 2. Simulated and observed snow depths at three of the study sites

where $D_{m, i}$ is the measured value and $D_{c, i}$ is the calculated value. $D_{a v}$ is the mean value of the measurements.

\section{Results}

SNOW MODEL

The whole data period 1981-2001 was used to calibrate the degree-day snow model to cover several different hydrological years. The model was able to explain the observed snow depths at all the five study sites. The $\mathrm{R}^{2}-$ values varied between a minimum of 0.80 at Jokioinen (1201) and a maximum of 0.92 at Sodankylä Observatory (7501). At Sodankylä Vuotso (8601), the $\mathrm{R}^{2}$-value was 0.89 , at Kuopio (3601) 0.91 and at Oulu (5401) 0.87. The parameter values obtained after calibrating the model are shown in Table 2. The observed and simulated snow depths at the southernmost, northernmost and coastal study sites 
Table 2. Calibrated parameter values of the degree day snow model

\begin{tabular}{|c|c|c|c|c|c|c|}
\hline \multirow[t]{2}{*}{ Parameter } & \multirow[t]{2}{*}{ Unit } & \multicolumn{4}{|c|}{ Observation Station } & \multirow[b]{2}{*}{8602} \\
\hline & & 1201 & 3601 & 5401 & 7501 & \\
\hline Min. value for degree-day factor & $\mathrm{mm} \mathrm{d}^{-1}{ }^{\circ} \mathrm{C}^{-1}$ & 2.84 & 1.82 & 3.60 & 2.50 & 1.60 \\
\hline Max. value for degree-day factor & $\mathrm{mm} \mathrm{d}^{-1}{ }^{\circ} \mathrm{C}^{-1}$ & 3.83 & 4.88 & 4.23 & 3.20 & 2.80 \\
\hline Increase in degree-day factor & $\mathrm{mm}^{-1}$ & 0.0044 & 0.023 & 0.0007 & 0.01 & 0.02 \\
\hline Refreexing parameter & $\mathrm{mm} \mathrm{d}^{-1}{ }^{\circ} \mathrm{C}^{-1}$ & 1.76 & 1.32 & 2.21 & 2.16 & 2.17 \\
\hline Base temp for refreezing & ${ }^{\circ} \mathrm{C}$ & -1.77 & -1.79 & -1.63 & -0.70 & -1.70 \\
\hline Exponent for refreezing & ${ }^{\circ} \mathrm{C}$ & 0.20 & 0.20 & 0.45 & 0.30 & 0.30 \\
\hline Max. retention capacity of snow & - & 0.016 & 0.077 & 0.005 & 0.12 & 0.12 \\
\hline Min. retention capacity of snow & - & 0.001 & 0.004 & 0.0015 & 0.05 & 0.05 \\
\hline Decr. in retention capacity of snow & $\mathrm{mm}^{-1}$ & 0.01 & 0.029 & 0.03 & 0.005 & 0.005 \\
\hline Base temperature for snowmelt & ${ }^{\circ} \mathrm{C}$ & 0.30 & -0.0036 & 0.74 & 0.15 & 0.15 \\
\hline Temperature limit precip. falls as snow & ${ }^{\circ} \mathrm{C}$ & -2.02 & -2.87 & -2.82 & -4.00 & -4.00 \\
\hline Temperature limit precip. falls as rainfall & ${ }^{\circ} \mathrm{C}$ & 3.70 & 1.81 & 0.27 & 0.00 & 0.00 \\
\hline Density of new snow & $\mathrm{kg} \mathrm{dm}{ }^{-3}$ & 0.12 & 0.12 & 0.12 & 0.12 & 0.12 \\
\hline Density of completely wet snow & $\mathrm{kg} \mathrm{dm}^{-3}$ & 0.32 & 0.32 & 0.36 & 0.36 & 0.36 \\
\hline Daily increase in snow density due to ageing & $\mathrm{d}^{-1}$ & 0.05 & 0.05 & 0.011 & 0.0098 & 0.0098 \\
\hline Correction factor for water & - & 1.05 & 1.05 & 1.05 & 1.05 & 1.05 \\
\hline Correction factor for snow & - & 1.28 & 1.28 & 1.28 & 1.28 & 1.28 \\
\hline
\end{tabular}

are presented in Fig. 2.

The degree-day model simulated, adequately, the duration of the snow cover as well as the date when snow started to accumulate and the date when snow cover melted away. Depth of the snow cover was simulated most accurately at Sodankylä Observatory (7501) (Fig. 2), where both meteorological variables and snow depth were measured at the same site. Winters at Sodankylä (7501 and 8601) were typically cold, with continuous snow cover. At Jokioinen (1201), the maximum snow depths were underestimated slightly during the years 1981-1990 (Fig. 2). During the years 1991-2001 measured snow depths were lower, and the snow model underestimated in some years and overestimated in others. The very mild winters between 1992 and 2000 were simulated rather well. At Oulu (5401), the snow model was unable to simulate all rapid snow accumulation and melting events in autumn (Fig. 2).

\section{SOIL TEMPERATURE MODEL}

The soil temperature model was calibrated to observed soil temperatures at depths of $20 \mathrm{~cm}$ and $50 \mathrm{~cm}$ for the period September 1981 to August 1990. The calibrated model was tested using observed soil temperatures from September 1990 to August 2001. The parameters used to calibrate the model are presented in Table 3 and the parameter values are within expected ranges. The $\mathrm{R}^{2}$-values for the calibration period varied between 0.87 and 0.96 at a depth of $20 \mathrm{~cm}$ and between 0.78 and 0.97 at a depth of $50 \mathrm{~cm}$ (Table 4). The $\mathrm{R}^{2}$-values for the testing period were between 0.87 and 0.94 at a depth of $20 \mathrm{~cm}$ and between 0.80 and 0.98 at a depth of $50 \mathrm{~cm}$.

The fit between modelled and observed snow depth for the calibration period was better at $20 \mathrm{~cm}$ than at $50 \mathrm{~cm}$ (Figs. 3-5). Although the $\mathrm{R}^{2}$-values for the calibration period were high at a depth of $50 \mathrm{~cm}$, some low soil temperatures were not reached (Jokioinen 1201) or a small time lag was

Table 3. Calibrated parameters of the soil temperature model.

\begin{tabular}{lllllll}
\hline Parameter & Unit & 1201 & 3603 & 5401 & 7501 & 8602 \\
\hline $\mathrm{C}_{\mathrm{S}}$ & $\mathrm{J} \mathrm{m}^{-3}{ }^{\circ} \mathrm{C}^{-1}$ & $1.30 \times 10^{6}$ & $1.30 \times 10^{6}$ & $1.10 \times 10^{6}$ & $1.00 \times 10^{6}$ & $1.00 \times 10^{6}$ \\
$\mathrm{~K}_{\mathrm{T}}$ & $\mathrm{W} \mathrm{m}^{-1}{ }^{\circ} \mathrm{C}^{-1}$ & 0.61 & 0.746 & 0.523 & 0.797 & 0.516 \\
$\mathrm{C}_{\text {ice }}$ & $\mathrm{J} \mathrm{m}^{-3}{ }^{\circ} \mathrm{C}^{-1}$ & $8.95 \times 10^{6}$ & $8.98 \times 10^{6}$ & $8.05 \times 10^{6}$ & $4.11 \times 10^{6}$ & $8.93 \times 10^{6}$ \\
$\mathrm{f}_{\mathrm{S}}$ & $\mathrm{m}^{-1}$ & -7.1 & -6.0 & -2.5 & -2.1 & -2.7 \\
\hline
\end{tabular}


Table 4. $\mathrm{R}^{2}$-values of the snow model for the calibration and test periods, and simulated and observed minimum and maximum values at the observation stations.

\begin{tabular}{|c|c|c|c|c|c|}
\hline & 1201 & 3603 & 5401 & 7501 & 8602 \\
\hline \multicolumn{6}{|l|}{ CALIBRATION PERIOD } \\
\hline \multicolumn{6}{|l|}{$20 \mathrm{~cm}$ depth: } \\
\hline $\mathrm{R}^{2}$-value & 0.95 & 0.96 & 0.94 & 0.90 & 0.87 \\
\hline Observed mean & 5.6 & 5.3 & 4.9 & 2.8 & 2.1 \\
\hline Simulated mean & 5.6 & 5.2 & 5.0 & 2.1 & 2.5 \\
\hline Observed min. value & -8.4 & -9.5 & -2.6 & -11.2 & -8.0 \\
\hline Simulated min. value & -6.4 & -11.1 & -5.7 & -20.7 & -10.6 \\
\hline Observed max. value & 19.5 & 21.1 & 21.7 & 23.0 & 15.0 \\
\hline Simulated max. value & 21.7 & 24.1 & 23.4 & 22.1 & 21.2 \\
\hline \multicolumn{6}{|l|}{$50 \mathrm{~cm}$ depth: } \\
\hline $\mathrm{R}^{2}$-value & 0.97 & 0.95 & 0.93 & 0.95 & 0.78 \\
\hline Observed mean & 5.8 & 5.5 & 4.8 & 2.7 & 2.2 \\
\hline Simulated mean & 5.7 & 5.6 & 5.2 & 3.0 & 3.5 \\
\hline Observed min. value & -4.3 & -2.9 & -1.1 & -10.1 & -5.5 \\
\hline Simulated min. value & -2.4 & -5.0 & -3.9 & -8.6 & -4.4 \\
\hline Observed max. value & 17.7 & 18.0 & 15.5 & 18.0 & 13.3 \\
\hline Simulated max. value & 18.4 & 19.7 & 17.8 & 17.7 & 15.4 \\
\hline \multicolumn{6}{|l|}{ TEST PERIOD } \\
\hline \multicolumn{6}{|l|}{$20 \mathrm{~cm}$ depth: } \\
\hline $\mathrm{R}^{2}$-value & 0.91 & 0.94 & 0.92 & 0.90 & 0.87 \\
\hline Observed mean & 6.8 & 5.8 & 4.6 & 2.5 & 2.3 \\
\hline Simulated mean & 5.7 & 5.4 & 5.1 & 2.7 & 3.0 \\
\hline Observed min. value & -3.0 & -3.6 & -1.5 & -4.1 & -6.6 \\
\hline Simulated min. value & -3.5 & -5.3 & -7.8 & -10.7 & -5.8 \\
\hline Observed max. value & 18.7 & 20.5 & 17.2 & 17.5 & 20.5 \\
\hline Simulated max. value & 22.0 & 22.5 & 20.9 & 21.2 & 20.4 \\
\hline \multicolumn{6}{|l|}{$50 \mathrm{~cm}$ depth: } \\
\hline $\mathrm{R}^{2}$-value & 0.97 & 0.95 & 0.90 & 0.98 & 0.80 \\
\hline Observed mean & 6.7 & 5.8 & 4.7 & 2.8 & 2.0 \\
\hline Simulated mean & 6.5 & 5.9 & 5.2 & 3.4 & 3.4 \\
\hline Observed min. value & -1.0 & -2.0 & -0.7 & -2.5 & -5.0 \\
\hline Simulated min. value & -0.8 & -2.9 & -2.3 & -4.4 & -3.4 \\
\hline Observed max. value & 16.6 & 17.8 & 14.8 & 16.0 & 12.6 \\
\hline Simulated max. value & 17.8 & 19.3 & 17.5 & 16.5 & 15.4 \\
\hline
\end{tabular}

seen between simulated and observed values (Sodankylä 8602). At Oulu (5401), simulated temperature peaks were lower than those measured (e.g. winters 1986-1987 and 1989-1990). An example of simulated and observed snow depths and soil temperatures during the winter of 19891990 is presented in Fig. 6. In December 1989, simulated soil temperatures were lower than the observed temperatures due to incorrect simulation of snow depth. The lowest $\mathrm{R}^{2}$ values were measured at Sodankylä (8602) where, conversely, the snow model gave the best calibration.
The simulated and observed mean, minimum and maximum temperatures during the calibration and testing period are presented in Table 4. Deviations between observed and simulated mean values was in most cases less than $1{ }^{\circ} \mathrm{C}$, except at Jokioinen Observatory (1201) at $20 \mathrm{~cm}$ depth during the testing period and at Sodankylä Vuotso (8602) at $50 \mathrm{~cm}$ depth during both the calibration and testing periods. The proposed soil temperature model generally predicts $1-2{ }^{\circ} \mathrm{C}$ higher maximum temperatures compared to measured maximum values, and simulated minimum 

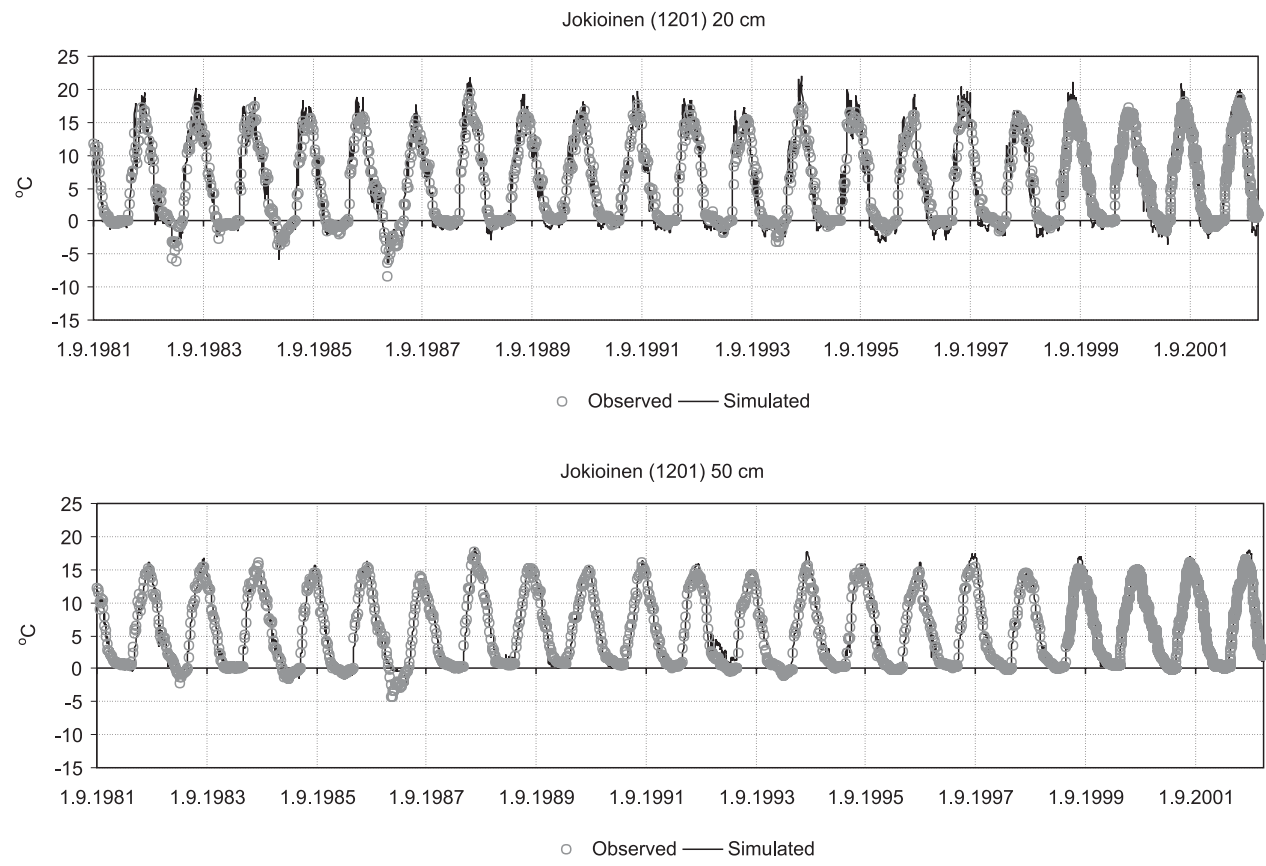

Fig. 3. Simulated and observed soil temperature at the depths of $20 \mathrm{~cm}$ and $50 \mathrm{~cm}$ at Jokioinen (1201)
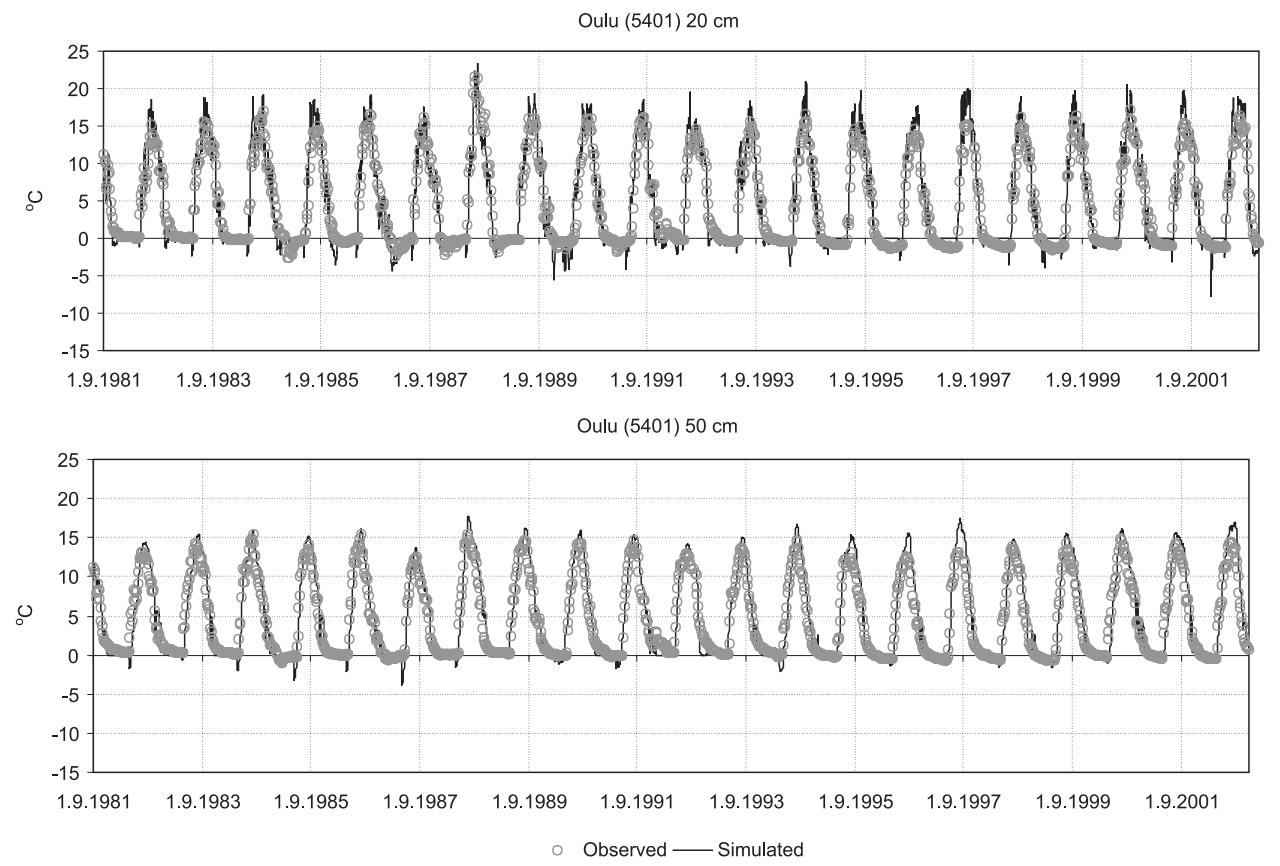

Fig. 4. Simulated and observed soil temperature at the depths of $20 \mathrm{~cm}$ and $50 \mathrm{~cm}$ at Oulu (5401)

temperatures were $1-2{ }^{\circ} \mathrm{C}$ lower than observed minimum values. The greatest difference between simulated and observed minimum temperature was seen at a depth of $20 \mathrm{~cm}$ at Sodankylä Observatory (7501). In most cases the $\mathrm{R}^{2}$-value for the testing period was only slightly lower than that for the calibration period.

\section{Discussion}

Three very important simplifications were made to derive the proposed soil temperature model from coupled water and heat flow equations. Firstly, soil water content was assumed to be constant throughout the computation. Secondly, no heat flow was assumed at the bottom of the profile. Thirdly, the effect of snow density on thermal 

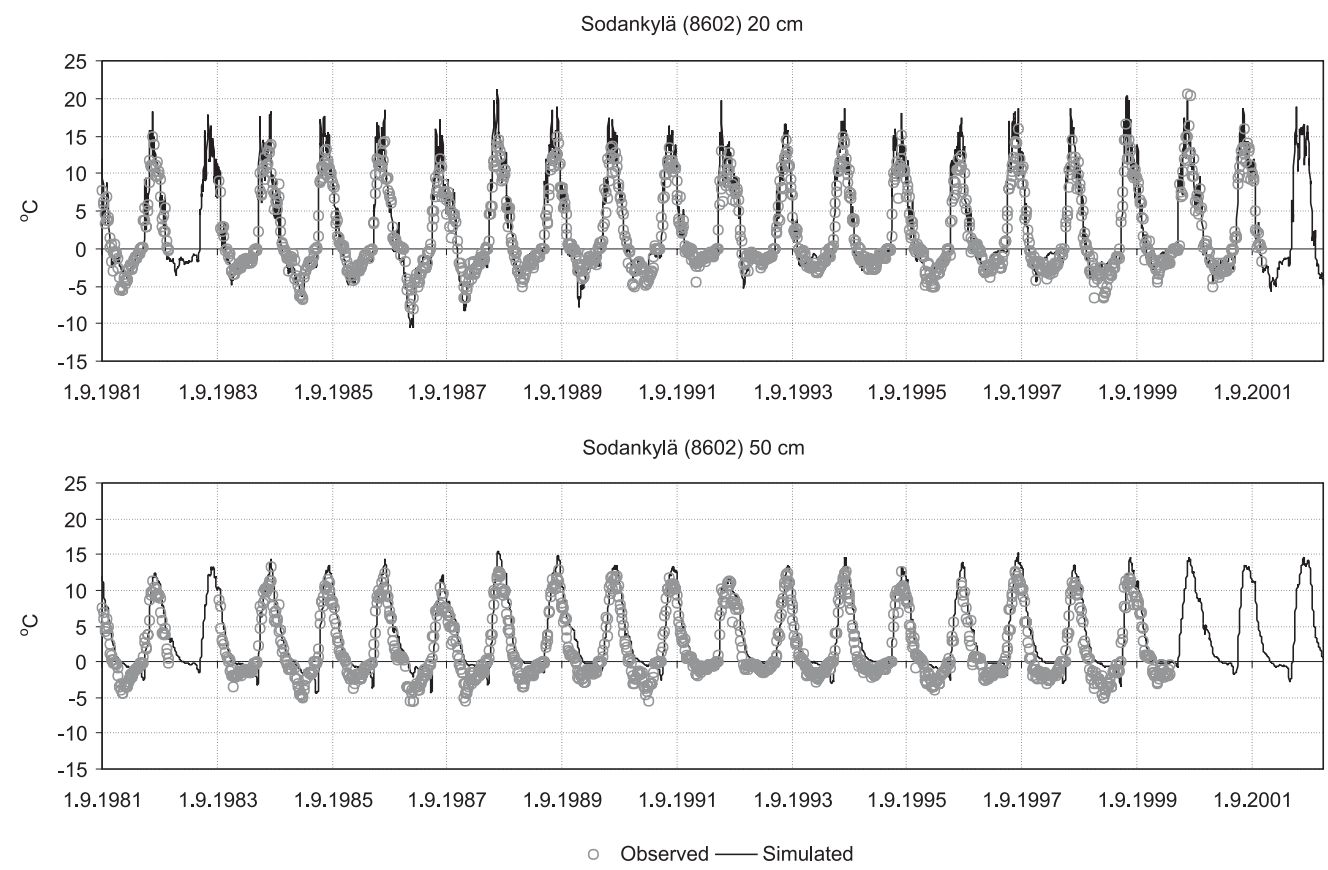

Fig. 5. Simulated and observed soil temperature at the depths of $20 \mathrm{~cm}$ and $50 \mathrm{~cm}$ at Sodankylä (8602)
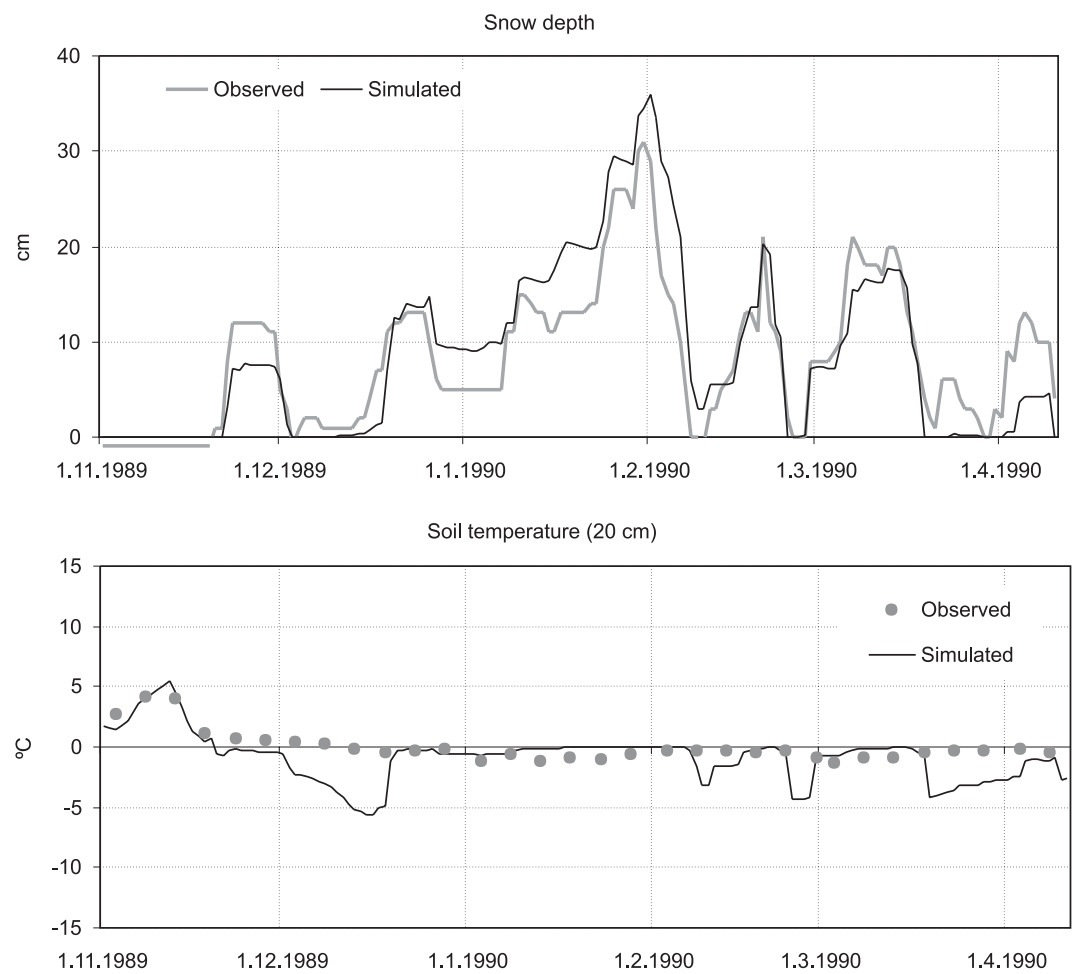

Fig. 6. Simulated and observed snow depths and soil temperatures at Oulu (5401) in winter 1989-1990.

conductivity of snow was neglected in the model.

The first simplification implies that the model is expected to underestimate the maximum soil temperatures in those summers when actual soil water content was below average because, in these cases, the true specific heat capacity will be smaller than the value used in the model, which should lead to underestimation of the soil temperature. However, the results given in Table 4 show that the calculated 
maximum values for soil temperature are higher than measured at depths of $20 \mathrm{~cm}$ and $50 \mathrm{~cm}$, except for Sodankylä Observatory (7501) at $20 \mathrm{~cm}$, which justifies the first simplification. In addition, the first simplification should cause the model to overestimate temperatures in cases in which the soil water content is low during the time when the soil is frozen; during such periods the model overestimates the influence of energy used for freezing water to ice. The results presented in Table 4 show that the minimum measured soil temperature is in most cases higher than the simulated one. According to these calibration results, the constant soil water content assumption does not lead to a systematic underestimation of high temperatures or overestimation of low temperatures.

The second simplification, that there is a no-flow heat boundary at the bottom of the profile, is expected to produce incorrect timing of the rising and falling part of the soil temperature curve. This can be seen clearly e.g. at the $50 \mathrm{~cm}$ depth in Sodankylä Vuotso (8602) (Fig. 5). During the melting phase the frozen layer receives energy from the deeper layer, but this is ignored in the model. At $20 \mathrm{~cm}$ depth, this phenomenon is not observed and as most $\mathrm{N}$ transformation takes place in the upper part of the profile, the proposed temperature model can be considered useful for providing input data to $\mathrm{N}$ models. To overcome these timing problems, it is suggested that future versions of the model should include heat entering through the lower boundary.

The third simplification was to ignore the effect of the density of snow on thermal conductivity and to enable the use of one parameter, $f_{S}$, that implicitly includes the effect of the thermal conductivity of snow. The effect of this simplification is very difficult to discern from the results, since these effects are usually of very short duration, occurring mainly either in the intensive melting phase in spring or, if snow disappears, during the winter months. Incorrect simulation of snow cover can be observed as peaks in the simulated soil temperature in winter. At Oulu (5401) (Fig. 4), peaks of lower temperature were simulated in winter. These peaks occured during rapid snow accumulation and melting periods, which were not simulated accurately by the degree-day snow model. This causes underestimation of soil temperature (Fig. 6). For the correct simulation of soil temperatures, it is important that the duration of the soil cover rather than snow density is described adequately. It is not necessary to complicate the snow model by including the density effect on snow thermal conductivity.

Calibrated parameter values of specific heat and thermal conductivity were in the range reported in the literature for different soil types (e.g. Tamm, 2002). In reality, the values of these parameters vary, depending on the water content of the soil, which is not included in the soil temperature model. $C_{\text {ice }}$ was between 8 and 9 at all sites except Sodankylä Observatory (7501), where its value was 4 , representing the properties of till soil. The value of parameter $f_{S}$ was between -2.1 and -7.1 at all sites.

\section{Conclusions}

Despite three important simplifications, the proposed soil temperature model has simulated soil temperature adequately at five observation stations in Finland. It is concluded that this simple model simulates soil temperature well in the uppermost soil layers where most nitrogen processes occur. The small number of parameters enables it to be included easily in catchment scale models.

\section{Acknowledgements}

This study was supported by the Commission of the European Union, the INCA project (EVK1-CT-199900011).

\section{References}

Clein, J.S. and Schimel, J.P., 1995. Microbial activity of tundra and taiga soils at sub-zero temperatures. Soil Biol. Biochem., 27, 1231-1234.

Drebs, A., Nordlund, A., Karlsson, P., Helminen, J. and Rissanen, P., 2002. Tilastoja Suomen ilmastosta 1971-2000. Climatological statistics of Finland 1971-2000. Finnish Meteorological Institute. Climatic statistics of Finland No. 2002:1, Helsinki, Finland. 99pp.

Guymon, G.L., Hromadka, T.V. and Berg, R.L., 1980. A onedimensional frost heave model based on simultaneous heat and water flux. Cold Reg. Sci. Technol., 3, 253-262.

Harlan, R.L., 1973. Analysis of coupled heat-fluid transport in partially frozen soil. Water Resour. Res., 9, 1314-1323.

Hämet-Ahti, L., 1981. The boreal zone and its biotic subdivision. Fennia, 159, 69-75.

Jansson, P.-E. and Karlberg, L., 2001. Coupled heat and mass transfer model for soil-plant-atmosphere systems. Royal Institute of Technolgy, Dept of Civl and Environmental Engineering, Stockholm. 325pp. (www.lwr.kth.se/CoupModel/ CoupModel.pdf).

Karvonen, T., 1988. A model for predicting the effect of drainage on soil moisture, soil temperature and crop yield. $\mathrm{PhD}$ thesis, Helsinki University of Technology, Laboratory of Water Resources, Otaniemi. 215pp.

Karvonen, T., 2003. Influence of global climatic change on different hydrological variables. (www.water.hut.fi/wr/kurssit/ Yhd-12.135/kirja/paa e.htm).

Kähkönen, M.A., Wittmann, C., Kurola, J., Ilvesniemi, H. and Salkinoja-Salonen, M.S., 2001. Microbial activity of boreal forest soil in a cold climate. Boreal Environ. Res., 6, 19-28.

Nash, J.E. and Sutcliffe, J.V., 1970. River flow forecasting through conceptual models, Part I -A discussion of principles. J. Hydrol., 10, 282-290. 
Persson, T. and Wirén, A., 1995. Nitrogen mineralization and potential nitrification at different depths in acid forest soils. Plant Soil, 168-169, 55-65.

Rankinen, K., Kaste, Ø. and Butterfield, D. 2004. Adaptation of the Integrated Nitrogen Model for catachments (INCA) to seasonally snow-covered catchments. Hydrol. Earth Syst. Sci., 8, 695-705.

Schmidt, I.K., Jonasson, S. and Michelsen, A., 1999. Mineralization and microbial immobilization of $\mathrm{N}$ and $\mathrm{P}$ in arctic soils in relation to season, temperature and nutrient amendment. . Appl. Soil Ecol., 11, 147-160.

Stanford, G., Frere, M.H. and Schwaninger, D.H., 1973. Temperature Coefficient of Soil Nitrogen Mineralization. Soil Sci., 115, 321-323.

Stottlemyer, R. and Toczydlowski, D., 1999. Nitrogen mineralization in a mature boreal forest, Isle Royale, Michigan. J. Environ. Qual., 28, 709-720.

Tamm, T., 2002. Effect of Meteorological Conditions and Water Management on Hydrological Processes in Agricultural Fields: Parameterization and Modeling of Estonian Case Studies. PhD thesis, Helsinki University of Technology Water Resources Publications, TKK-VTR-5, Espoo, 194pp (www.water.hut.fi/ $\mathrm{wr} /)$.
Taylor, G.S. and Luthin, J.N., 1978. A model for coupled heat and moisture transfer during soil freezing. Can. Geotech. J., 15, 548-555.

Vehviläinen, B., 1992 Snow cover models in operational watershed forecasting. National Board of Waters and the Environment, Finland. Publications of Water and Environment Research Institute. $112 \mathrm{pp}$.

Venäläinen, A., Tuomenvirta, H., Lahtinen, R. and Heikinheimo, M., 2001. The influence of climate warming on soil frost on snow-free surfaces in Finland. Climatic Change, 50, 111-128.

Vitousek, P.M., Aber, J.D., Howarth, R.W., Likens, G.E., Matson, P.A., Schindler, D.W., Schlesinger, W.H. and Tilman, D.G., 1997. Human alteration of the global nitrogen cycle: sources and consequences. Ecol. Appl., 7, 737-750. 